\title{
PENGARUH PENGGUNAAN PECAHAN GENTENG DAN PENAMBAHAN FLY ASH TERHADAP KUAT TEKAN SEGMEN KOLOM MODULAR DAN BEBAN AKSIAL KOMPONEN KOLOM SEBAGAI SUPLEMEN BAHAN AJAR MATA KULIAH TEKNOLOGI BETON
}

\author{
Handri Setia $\mathbf{P}^{1}$, Chundakus Habsya ${ }^{2}$, Taufiq Lilo Adi $\mathbf{S}^{3}$ \\ Pendidikan Teknik Bangunan, Universitas Sebelas Maret \\ Email: setiahandri@gmail.com
}

\begin{abstract}
Abstrak: Penelitian ini bertujuan untuk mengetahui: (1) pengaruh penggunaan pecahan genteng dan penambahan fly ash terhadap kuat tekan segmen kolom modular, (2) pengaruh penggunaan pecahan genteng dan penambahan fly ash terhadap beban aksial komponen kolom, (3) mengetahui persentase optimal penggunaan pecahan genteng dan penambahan fly ash yang menghasilkan kuat tekan maksimal segmen kolom modular, (4) mengetahui persentase optimal penggunaan pecahan genteng dan penambahan fly ash yang menghasilkan beban aksial maksimal komponen kolom.

Metode yang digunakan dalam penelitian ini adalah metode kuantitatif dengan penelitian eksperimental yang dilakukan di laboratorium. Sampel yang digunakan segmen kolom berbentuk kubus dengan ukuran $150 \mathrm{~mm} \times 150 \mathrm{~mm} \times 150 \mathrm{~mm}$ dengan lubang pada tengah berukuran $80 \mathrm{~mm} \times 80 \mathrm{~mm}$ x150 mm sebanyak 36 buah untuk pengujian kuat tekan segmen kolom modular. Dan sampel uji beban aksial komponen kolom dengan ukuran $150 \mathrm{~mm}$ x $150 \mathrm{~mm}$ x $600 \mathrm{~mm}$ sebanyak 36 buah untuk pengujian beban aksial komponen kolom. Jumlah seluruh benda uji 72 buah. Persentase penggunaan pecahan genteng $0 \%, 20 \%, 40 \%$, dan $60 \%$ terhadap berat pasir. Sedangkan persentase penambahan fly ash terhadap berat agregat halus $0 \%, 15 \%$ dan $30 \%$. Pengujian kuat tekan segmen kolom modular dan beban aksial komponen kolom dilakukan saat umur beton 28 hari.

Hasil penelitian sebagai berikut, (1) Penggunaan pecahan genteng berpengaruh negatif terhadap kuat tekan segmen kolom modular dan penggunaan fly ash berpengaruh positif terhadap kuat tekan segmen kolom modular, (2) Penggunaan pecahan genteng berpengaruh negatif terhadap beban aksial komponen kolom dan penggunaan fly ash bersifat positif terhadap beban aksial komponen kolom. (3) Nilai optimal kuat tekan segmen kolom adalah $13,95 \mathrm{MPa}$ pada persentase $20 \%$ penggunaan pecahan genteng dan $30 \%$ penambahan fly ash. (4) Nilai optimal beban aksial komponen kolom adalah 133,33 KN pada persentase $20 \%$ penggunaan pecahan genteng dan $30 \%$ penambahan fly ash.
\end{abstract}

Kata kunci: segmen kolom modular, kuat tekan segmen kolom, beban aksial komponen kolom, pecahan genteng, fly ash

\footnotetext{
${ }^{1}$ Mahasiswa Program Studi Pendidikan Teknik Bangunan FKIP UNS.

${ }^{2}$ Pembimbing I Chundakus Habsya

3

II Taufiq Lilo Adi S
} 


\title{
The Effect Of Tile Fraction And Addition Of Fly Ash To The Compressive Strength \\ Of Modular Column Segment And Axial Load Of Column Components As A Supplement To The Study Of Conrete Technology Courses
}

\author{
Handri Setia $\mathbf{P}^{1}$, Chundakus Habsya ${ }^{2}$, Taufiq Lilo Adi $S^{3}$ \\ Pendidikan Teknik Bangunan, Universitas Sebelas Maret \\ Email: setiahandri@gmail.com
}

\begin{abstract}
The purpose of this research were: (1) the effect of roof tile fractions and addition of fly ash to compressive strength of the concrete column segment,(2) the effect of roof tile fractions and addition of fly ash to axial load Of Column Components, (3) determine an optimum percentage of roof tile fractions and addition of fly ash which produces a maximum compressive strength of the concrete column segment, and (4) determine an optimum percentage of roof tile fractions and addition of fly ash which produces a maximum axial load of the column components.
\end{abstract}

The method used in this research was quantitative method of experimental research design that conducted in the laboratory. The sample used is a cube-shaped column segment of a size of $150 \mathrm{~mm} \times 150 \mathrm{~mm} \times 150 \mathrm{~mm}$ with a hole in the middle of 80 $m m \times 80 \mathrm{~mm} \times 150 \mathrm{~mm}$ sizes of 36 pieces for testing the compressive strength of concrete column segments and axial load columns components with the size $150 \mathrm{~mm} x$ $150 \mathrm{~mm} \mathrm{X} 600 \mathrm{~mm}$ for 36 pieces for testing the compressive strength of the segment column components. Percentage of roof tile fraction use is $0 \%, 20 \%, 40 \%$, and $60 \%$ to the weight of sand. While the percentage of fly ash addition to the volume of concrete is $0 \%, 15 \%$ and $30 \%$. Segment compressive strength testing of concrete column segment and column components segment performed at the concrete age for 28 days.

The result of this research (1) The use of fractional tile and the addition of fly ash have an effect on the compressive strength of the column segment, (2) The use of fractional tile and the addition of fly ash affect the axial load of column components. (3) The optimum value of the compressive strength of the concrete column segment is 13.95 $\mathrm{MPa}$ at a 20\% percentage of roof tile fraction uses and 30\% addition of fly ash, (4) The optimum value of the axial load of the column components is $133,33 \mathrm{KN}$ at a $20 \%$ percentage of roof tile fraction uses and $30 \%$ addition of fly ash.

Keyword: concrete column segment, compressive strength, axial load, fly ash, tile fraction

\footnotetext{
${ }^{1}$ Mahasiswa Program Studi Pendidikan Teknik Bangunan FKIP UNS.

${ }^{2}$ Pembimbing I Chundakus Habsya

3

II Taufiq Lilo Adi S
} 
PENDAHULUAN

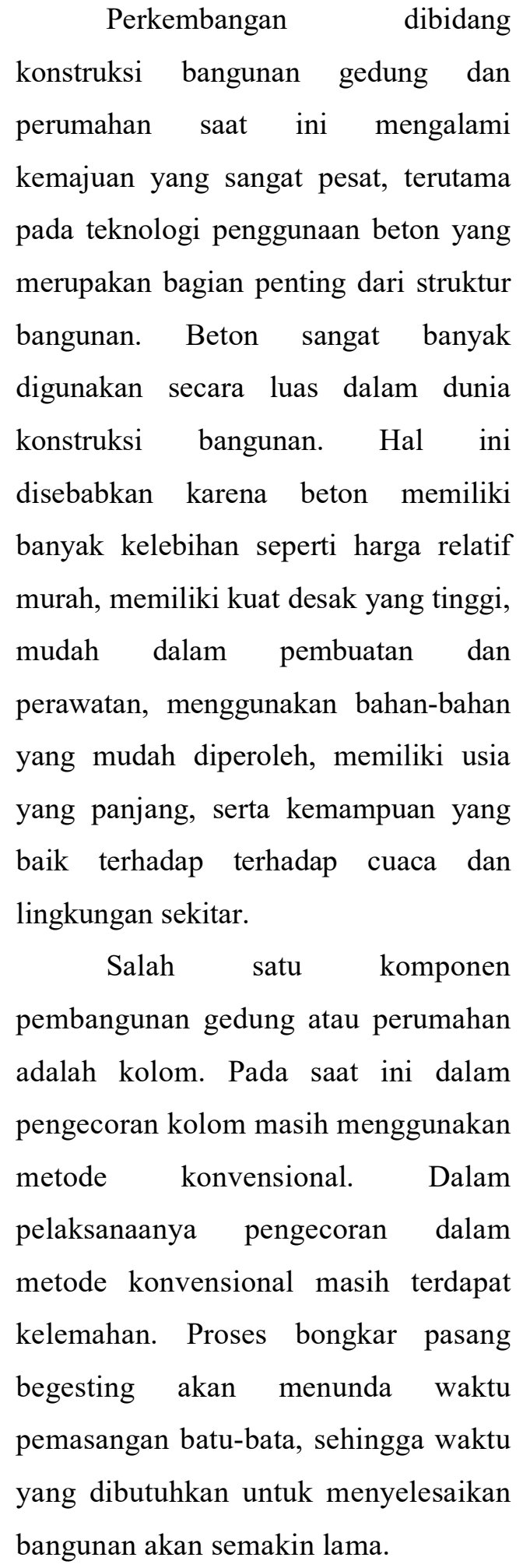

Solusi untuk mempersingkat waktu dalam pengerjaan bangunan bisa menggunakan komponen prapabrikasi. Komponen prapabrikasi kolom memiliki keunggulan seperti pemasangan kolom dapat disusun dan langsung dicor tanpa harus memasang begesting. Pemasangan batu bata bisa langsung dikerjakan bersamaan dengan prosen penyusunan kolom. Dari hal tersebut penggunaan prapabrikasi kolom akan mempersingkat waktu pengerjaan bangunan.

Prapabrikasi komponen bangunan yang telah ada antara lain temuan Nagy,dkk (2012), Modular Concrete Building yaitu prapabrikasi komponen bangunan yang terdiri dari komponen kolom, balok, panel lantai, panel dinding, dan panel atap yang terbuat dari beton.

Menurut Dwi Dinariana (2013:327), pengertian konstruksi beton prapabrikasi (pracetak) adalah suatu konstruksi bangunan yang komponen bangunannya dipabrikasi/dicetak terlebih dahulu di pabrik atau di lapangan, lalu disusun di lapangan untuk membentuk satu kesatuan bangunan gedung. Sehingga sistem ini memiliki banyak kelebihan diantaranya: hemat waktu, hemat biaya, mutu mudah

\footnotetext{
${ }^{1}$ Mahasiswa Program Studi Pendidikan Teknik Bangunan FKIP UNS.

${ }^{2}$ Pembimbing I Ir. Chundakus Habsya 
dikontrol, produktivitasnya tinggi karena bisa dibuat misal, ramah lingkungan, dan inovatif.

Berdasarkan uraian diatas bisa dimungkinkan untuk melakukan prapabrikasi komponen kolom secara masal dengan membuat segmen kolom modular.

Segmen kolom modular merupakan segmen kolom dari beton berbentuk segi empat berdimensi modular, masing-masing dinding luar segmen kolom modular terdapat takikan berbentuk trapesium untuk perkuatan sambungan dengan dinding atau kusen, memiliki lubang di tengah untuk rangkaian tulangan dan adukan beton. Dapat digunakan untuk berbagai tinggi kolom bangunan gedung sesuai dengan kelipatan dimensi modul. (gambar 1).

Dengan adanya segmen kolom modular ini dapat mempercepat waktu pelaksanaan pembangunan rumah hunian.

Yang menjadi kendala adalah belum adanya penelitian tentang kekuatan segmen kolom modular dengan bahan alternatif lainnya. sehingga perlu diadakan penelitian.

Selain meneliti kekuatan segmen kolom modular perlu diadakannya komponen kolom.
Komponen kolom merupakan susunan dari segmen kolom modular yang tengahnya deberi tulangan dan campuran agregat beton.(gambar 2).

Mengingat kebutuhan akan agregat sebagai bahan campuran beton semakin meningkat, akan tetapi jumlah agregat yeng tersedia di alam bisa habis jika digunakan secara terusmenerus, maka dari itu wajib mencari alternatif lain pengganti material tersebut dengan tidak mengurangi kualitas dan kekuatan beton bertulang terutama segmen kolom modular jika dipakai sebagai elemen struktur bangunan.

Ada banyak bahan pengganti material beton khususnya agregat kasar seperti pecahan batako, pecahan genteng, pecahan batu bata dan masih banyak lagi, semua itu dapat kita manfaatkan menjadi material pengganti dan bahan tambah pada pembuatan beton. Penggunaan material pengganti pada beton akan berpengaruh terhadap kekuatan beton.

Genteng merupakan bagian utama dari suatu bangunan sebagai penutup atap rumah. Jenis genteng bermacam-macam, ada genteng beton, genteng tanah liat, genteng keramik, genteng seng dan genteng kayu (sirap).

\footnotetext{
${ }^{1}$ Mahasiswa Program Studi Pendidikan Teknik Bangunan FKIP UNS.

${ }^{2}$ Pembimbing I Chundakus Habsya 
Keunggulan genteng tanah liat (lempung) selain murah, bahan ini tahan segala cuaca, dan lebih ringan dibanding genteng beton. Sedangkan kelemahannya, genteng ini bisa pecah karena kejatuhan benda atau menerima beban tekanan yang besar melebihi kapasitasnya. Kualitas genteng sangat ditentukan dari bahan dan suhu pembakaran, karena hal tersebut akan menentukan daya serap air dan daya tekan genteng. (Aryadi. Y, 2010).

Penggunaan pecahan genteng tanah liat untuk agregat dimungkinkan masih terdapat kelemahan. Daya serap air yang tinggi pada pecahan genteng bisa disebabkan karena banyaknya poripori atau rongga pada pecahan genteng sehingga pada rongga tersebut akan diisi oleh udara. Oleh karena itu diperlukan material yang sangat lembut yang dapat mengisi rongga. Salah satu bahan yang memungkinkan digunakan adalah abu terbang atau fly ash.

Fly ash atau abu terbang yang merupakan sisa-sisa pembakaran batu bara, yang dialirkan dari ruang pembakaran melalui ketel berupa semburan asap, yang berbentuk partikel halus dan merupakan bahan anorganik yang terbentuk dari perubahan bahan mineral karena proses pembakaran batu bara pada unit pembangkit uap (boiler), dan akan terbentuk dua jenis abu yaitu abu terbang (fly ash) dan abu dasar (bottom ash).

Sebagai sebuah campuran, abu terbang (fly ash) berfungsi baik sebagai pengganti atau bahan tambah untuk semen Portland dan bisa ditambahkan langsung ke dalam campuran beton di batching plant (E. Aydin, 2009). Material ini mempunyai kadar bahan semen yang tinggi dan mempunyai sifat pozzolanik. Kandungan fly ash sebagian besar terdiri dari silikat dioksida $\left(\mathrm{SiO}_{2}\right)$, aluminium $\left(\mathrm{Al}_{2} \mathrm{O}_{3}\right)$, besi $\left(\mathrm{Fe}_{2} \mathrm{O}_{3}\right)$ dan kalsium $(\mathrm{CaO})$, serta magnesium, potassium, sodium, titanium, dan sulfur dalam jumlah yang lebih sedikit (Nugraha, P dan Antoni, 2007:104)

Menurut ACI Committee 226 dijelaskan bahwa, fly ash mempunyai butiran yang cukup halus, yaitu lolos ayakan N0. 325 (45 mili mikron) 5$27 \%$, dengan spesific gravity antara 2,15-2,8 dan berwarna abu-abu kehitaman. Sifat proses pozzolanic dari fly ash mirip dengan bahan pozzolan lainnya. Menurut ASTM C.618 (ASTM, 1995:304) abu terbang (fly ash) didefinisikan sebagai butiran halus residu pembakaran batu bara atau bubuk batu bara.

${ }^{1}$ Mahasiswa Program Studi Pendidikan Teknik Bangunan FKIP UNS.

${ }^{2}$ Pembimbing I Chundakus Habsya

$3 \quad$ II Taufiq Lilo Adi S 


\section{METODOLOGI PENELITIAN}

Penelitian ini menggunakan metode kuantitatif (uji normalitas,uji multikolinieritas,uji heteroskedastisitas) dengan pendekatan eksperimen yang dilaksanakan di laboratorium dengan kondisi dan perlengkapan yang disesuaikan dengan kebutuhan untuk mendapatkan data tentang kuat tekan segmen kolom modular dan beban aksial komponen kolom dengan menggunakan pecahan genteng dan bahan tambah fly ash.

Populasi pada penelitian ini adalah benda uji segmen kolom modular dengan dimensi $15 \mathrm{~mm}$ x 15 mm x 15 mm sebanyak 36 buah untuk pengujian kuat tekan segmen.

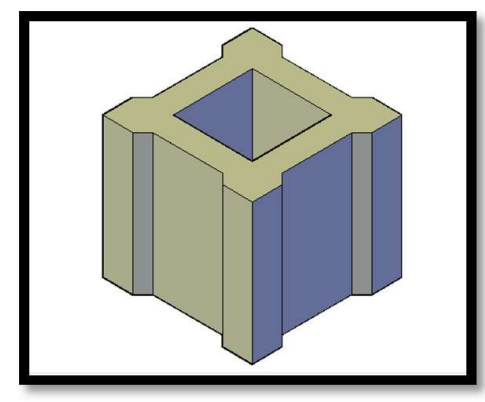

Gambar 1. Benda uji segmen kolom modular

Benda uji komponen kolom merupakan susunan beberapa segmen kolom dengan dimensi $15 \mathrm{~mm}$ x $15 \mathrm{~mm}$ x $600 \mathrm{~mm}$. Bagian tengah diberi tulangan dan diisi campuran beton normal (perbandingan campuran 1:2:3).
Jumlah benda uji sebanyak 36 buah untuk pengujian beban aksial komponen kolom.

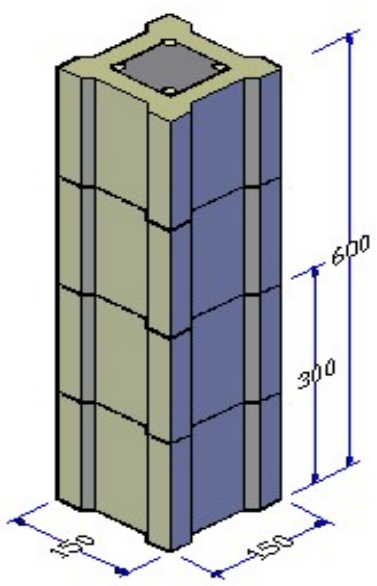

Gambar 2. Benda uji komponen kolom

Data primer merupakan data yang diperoleh dari penelitian atau eksperimen dan pengamatan yang dilakukan di laboratorium. Hasil data diantaranya adalah data-data uji bahan yang dilakukan sebelum pembuatan benda uji, dan data hasil uji kuat tekan segmen kolom modular beton dan uji kuat tekan komponen kolom segmen. Data sekunder didapat dari literatur/referensi berupa buku-buku relevan dan jurnal penelitian yang dapat menunjang berlangsungnya penelitian ini.

Bahan alat yang digunakan dalam penelitian ini adalah

a) Semen tipe I yaitu menggunakan semen merk Gresik.

\footnotetext{
${ }^{1}$ Mahasiswa Program Studi Pendidikan Teknik Bangunan FKIP UNS.

${ }^{2}$ Pembimbing I Chundakus Habsya

$3 \quad$ II Taufiq Lilo Adi S
} 
b) Agregat halus yang digunakan diambil dari daerah Muntilan, Magelang.

c) Air yang digunakan adalah air dari Laboraturium Pendidikan Teknik Bangunan FKIP Universitas Sebeleas Maret Surakarta.

d) Pecahan genteng diperoleh dari pengrajin genteng dari Boyolali, Jawa Tengah.

e) Abu terbang atau fly ash yang digunakan diperoleh dari PT. SCG Jayamix, Mojosongo, Surakarta.

Pembuatan benda uji berdasarkan perhitungan rencana adukan. Percampuran bahan dilakukan pada saat diaduk dalam mixer dengan mencampurkan agregat halus (pasir), pecahan genteng, semen dan fly ash terlebih dahulu. Setelah pasir, pecahan genteng, semen dan fly ash tercampur rata, kemudian penambahan air dilakukan sedikit-sedikit hingga adukan bercampur merata dan menggumpal.

Jika campuran terlihat sudah merata namun belum bisa menggumpal, maka adonan campuran tersebut perlu ditambahkan air secukupnya hingga adonan campuran memenuhi kriteria yaitu dengan memeriksa campuran: ambil segenggam penuh adukan dan bentuk seperti bola kecil. Jika bola tersebut tidak pecah dan tangan sedikit basah, adukan siap untuk dicetak (Claudia, dkk., 2006)

Ketika pengadukan bahan oleh mesin pengaduk (mixer) harus dilakukan perataan bahan secara manual juga menggunakan cetok, hal ini dikarenakan adonan ketika diaduk menggumpal dibagian tangkai mixer. Pencetakan dilakukan setiap variasi adukan beton telah selesai dari pengadukan oleh mixer. Dalam waktu yang bersamaan ketika pengadukan menggunakan mixer, persiapan mesin pencetak dengan memasang alas cetakan dimesin pencetak dengan menurunkan cetakan tepat diatas alas cetakan dengan tuas penggerak cetakan.

Adukan yang telah homogen dimasukkan dalam cetakan secara bertahap dan unit penggetar dihidupkan sampai adukan penuh. Kemudian tutup cetakan dengan mengunakan tuas penggerak cetakan, angakat tuas keatas sampai tutup cetakan jatuh dan menekan adukan dalam cetakan. Kemudian getarkan unit penggetar dengan menggunakan pedal pada bagian bawah mesin hingga penutup cetakan berada pada batas yang ditandai

${ }^{1}$ Mahasiswa Program Studi Pendidikan Teknik Bangunan FKIP UNS.

${ }^{2}$ Pembimbing I Chundakus Habsya

$3 \quad$ II Taufiq Lilo Adi S 
sehingga produk benda uji diharapan sesuai dengan yang direncanakan.

Unit penggetar dimatikan dan cetakan bersama tutup cetakan dinaikkan dengan tuas penggerak cetakan hingga diatas produk. Produk segmen kolom beton selesai dicetak, kemudian produk dipindahkan dan dilakukan perawatan di rak yang tidak terkena sinar matahari langsung supaya proses pengeringan bertahap sehingga tidak terjadi retak-retak.

Untuk membuat benda uji komponen kolom, segmen kolom modular yang telah jadi disusun terlebih dahulu tanpa menggunakan spasi. Pada penelitian ini digunakanlah komponen kolom dengan dimensi $150 \mathrm{~mm} \times 150$ $\mathrm{mm}$ dan tinggi $600 \mathrm{~mm}$. Bagian tengah diberi tulangan dan diisi dengan campuran beton normal (perbandingan campuran 1:2:3).

\section{PENGUJIAN}

\section{Kuat tekan segmen kolom modular}

Kuat tekan beban beton adalah besarnya beban per satuan luas, yang menyebabkan benda uji beton hancur bila dibebani dengan gaya desak tertentu, yang dihasilkan oleh mesin desak (SNI-03-1974-1990).

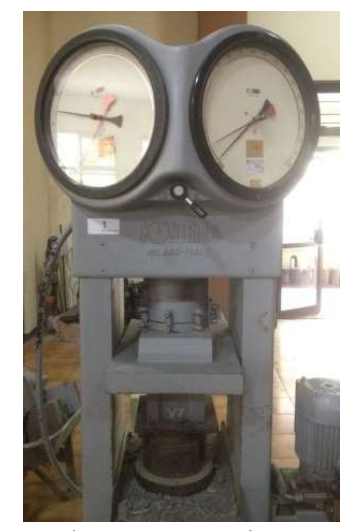

Gambar 3. Mesin CTM

Cara pengujian menurut SNI03-1974-1990, harus diikuti beberapa tahapan sebagai berikut:

1) Letakkan benda uji pada mesin tekan secara sentris;

2) Jalankan mesin tekan dengan penambahan beban yang konstan berkisar antara 2 sampai $4 \mathrm{~kg} / \mathrm{cm}^{2}$ per detik;

3) Lakukan pembebanan sampai uji menjadi hancur dan catatlah beban maksimum yang terjadi selama pemeriksaan benda uji;

4) Gambar bentuk pecah dan catatlah keadaan benda uji.

Rumus Perhitungan:

Kuat tekan beton $=\frac{P}{A}\left(\mathrm{~kg} / \mathrm{cm}^{2}\right)$

Keterangan:

$\mathrm{P}=$ beban maksimum $(\mathrm{kg})$

$\mathrm{A}=$ luas penampang $\left(\mathrm{cm}^{2}\right)$

\footnotetext{
${ }^{1}$ Mahasiswa Program Studi Pendidikan Teknik Bangunan FKIP UNS.

${ }^{2}$ Pembimbing I Chundakus Habsya

3 II Taufiq Lilo Adi S
} 


\section{Beban aksial komponen kolom}

Kolom bangunan sebagai

HASIL PENELITIAN DAN bagian dari sutau kerangka bangunan memiliki fungsi dan posisi penting dalam sistem struktur bangunan. Kegagalan kolom akan berakibat langsung pada runtuhnya komponen struktur lain yang berhubungan dengannya, atau bahkan merupakan batas runtuh total keseluruhan struktur bangunan (Gunawan. P, 2011).

Dengan demikian pentingnya mengetahui besarnya nilai kekuatan menahan beban aksial (satuan: KN) suatu kolom sebelum kolom tersebut digunakan sebagai struktur bangunan.

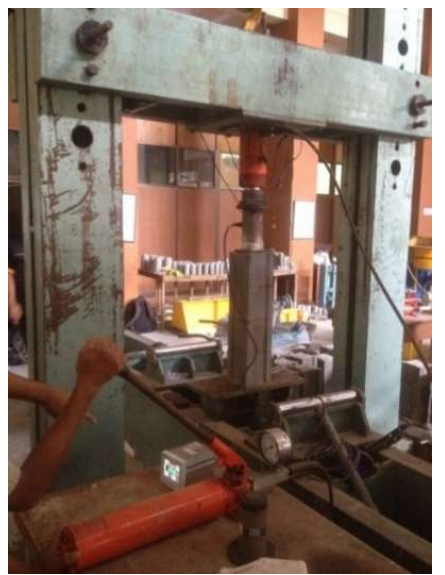

\section{PEMBAHASAN}

\section{Hasil Pengujian Kuat Tekan} Segmen Kolom Modular

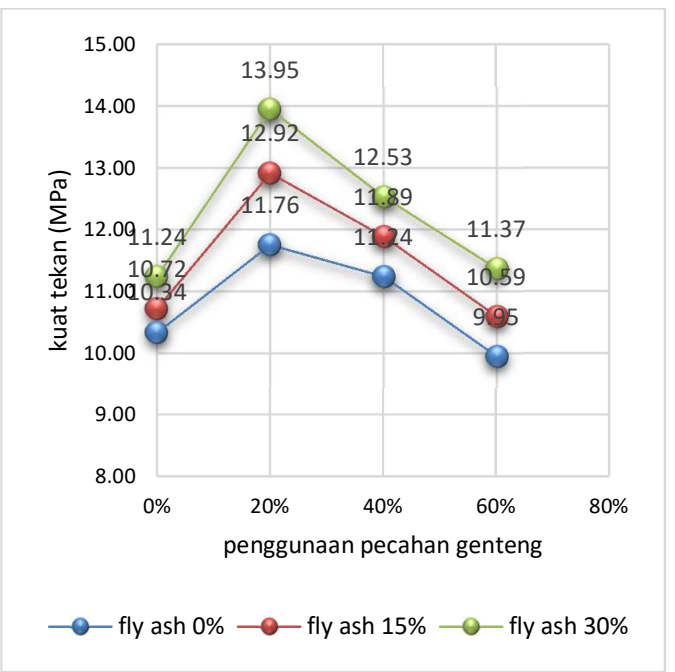

Gambar 5. hasil rata-rata kuat tekan segmen kolom modular

\section{Hasil pengujian beban aksial komponen kolom}

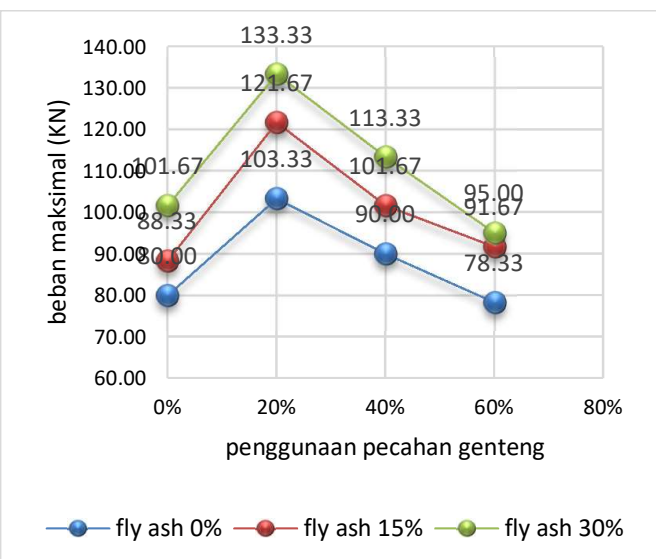

Gambar 4 Alat Uji Kekuatan Beban Aksial Kolom

Alat ujia aksial diatas dilakukan

Gambar 6. hasil rata-rata pengujian beban aksial komponen kolom

untuk pengujian kekuatan menahan beban aksial kolom

\footnotetext{
${ }^{1}$ Mahasiswa Program Studi Pendidikan Teknik Bangunan FKIP UNS.

${ }^{2}$ Pembimbing I Chundakus Habsya

$3 \quad$ II Taufiq Lilo Adi S
} 


\section{Pembahasan}

Berdasarkan gambar 5 Nilai kuat tekan rata-rata segmen kolom tertinggi dari penelitian ini yaitu 13,95 Mpa pada persentase penggunaan pecahan genteng 20\% dan penambahan fly ash 30\%. Sedangkan gambar 6 menunjukkan beban aksial rata-rata komponen kolom tertinggi dari penelitian ini yaitu $133,33 \mathrm{KN}$ pada persentase penggunaan pecahan genteng $20 \%$ dan penambahan fly ash $30 \%$.

Pada penelitian Ahmad Mashadi,dkk (2009:66-84) penggantian pecahan genteng dari kerikil untuk paving blok bisa meningkatkan kekuatan hingga persentase $60 \%$ dengan kekuatan $162,2 \mathrm{~kg} / \mathrm{cm}^{2}$ dengan peningkatan kekuatan sebesar 57\% dari paving blok normal yang memiliki kekuatan $103,30 \mathrm{~kg} / \mathrm{cm}^{2}$. Namun pada penelitian ini penggantian pecahan genteng hanya meningkatkan nilai kuat tekan segmen kolom pada variasi $0 \%$ - 20\%. Nilai kuat tekan beton segmen kolom sudah mengalami penurunan kekuatan mulai variasi penggantian pecahan genteng $40 \%$, dan $60 \%$.
Penggantian pecahan genteng yang semakin banyak justru bernilai negatif, artinya semakin banyak penambahan pecahan genteng akan berakibat pada menurunnya kuat tekan pada segmen kolom beton. Hal ini juga disebutkan dalam penelitian Warsiti (2007:72-77) Hubungan antara persentase pecahan genteng terhadap kuat tekan beton adalah berbanding terbalik artinya semakin besar (banyak ) persentase pecahan genteng semakin kecil kuat tekan beton yang terjadi. Hasil dari penelitian ini menunjukan bahkan penggunaan pecahan genteng mengalami penurunan kekuatan secara gignifikan pada persentase $20 \%$ dengan penurunan kekuatan sebesar $14,08 \%$.

Menurunnya kuat tekan pada semakin banyaknya penggunaan pecahan genteng bisa disebabkan beberapa faktor seperti tingginya kadar air pada genteng bisa menjadi salah satu faktor, hal ini dikarenakan air yang seharusnya membuat semen menjadi pasta yang dapat mengikat agregat, menjadi berkurang dikarenakan air sudah banyak terserap ke genteng.

\footnotetext{
${ }^{1}$ Mahasiswa Program Studi Pendidikan Teknik Bangunan FKIP UNS.

${ }^{2}$ Pembimbing I Chundakus Habsya

3 II Taufiq Lilo Adi S
} 
Hal tersebut juga dinyatakan oleh Mersyanti,dkk (2007) yang menyatakan beton dengan penambahan pecahan genteng jenis K-175 tidak memiliki kuat tekan sesuai rencana disebabkan karena genteng memiliki kadar penyerapan, kadar air, dan kadar lumpur yang tinggi.

Selain itu tingkat kekerasan pecahan genteng yang rendah bisa mengakibatkan menurunnya kuat tekan segmen kolom jika penggunaan pecahan genteng semakin banyak.

Sedangkan penambahan fly ash dengan variasi $0 \%, 15 \%$, dan $30 \%$ memberikan pengaruh baik yaitu dapat meningkatkan nilai kuat tekan beton segmen kolom beton. Penambahan fly ash memberikan nilai positif artinya dengan penambahan fly ash dapat memberikan kuat tekan lebih dibandingkan tanpa penggunaan fly ash. Penggunaan fly ash tertinggi didapatkan pada persentase penambahan fly ash sebesar 30\%. Meningkatnya kuat tekan segmen kolom ini bisa disebabkan dari beberapa faktor seperti ukuran butiran fly ash yang sangat lembut.
Menurut ACI Committee 226, dijelaskan bahwa abu terbang (fly ash) mempunyai butiran yang cukup halus, yaitu lolos ayakan No. 325 (45 mili mikron). Dengan ukuran yang sangat kecil sehingga memungkinkan butiran-butiran fly ash bisa mengisi pori-pori pada segmen kolom beton sehingga dapat meningkatkan kuat tekan pada kuat tekan segmen.

Selain itu fly ash akan memiliki kemampuan mengikat jika bercampur dengan semen dan ditambahkan dengan air. Hal tersebut bisa membantu fungsi semen sebagai perekat sehingga penggunaan fly ash dapat meningkatkan kuat tekan pada segmen kolom. Hal ini juga sesuai dengan penelitian Ginanjar Bagus P,dkk (2015) yang menggunakan fly ash sepenuhnya dan dilakukan penambahan Na2SiO3 (sodium silikat) dan $\mathrm{NaOH}$ (sodium hidroksida) untuk menggantikan semen pada beton geopolymer yang menghasilkan beton dengan kekuatan tertinggi $141,037 \mathrm{~kg} / \mathrm{cm}^{2}$.

Djiwantoro, $(2001)$ mengungkapkan bahwa abu terbang tidak memiliki kemampuan mengikat seperti halnya semen, namun dengan kehadiran air dan ukurannya yang

${ }^{1}$ Mahasiswa Program Studi Pendidikan Teknik Bangunan FKIP UNS.

${ }^{2}$ Pembimbing I Chundakus Habsya

3 II Taufiq Lilo Adi S 
halus, oksida silika yang dikandung didalam abu batubara akan bereaksi secara kimia dengan kalsium hidroksida yang terbentuk dari proses hidrasi semen dan akan menghasilkan zat yang memiliki kemampuan yang mengikat.

\section{KESIMPULAN DAN SARAN}

1. Simpulan

Berdasarkan Hasil penelitian dan pembahasan dapat disimpulkan bahwa:

a. Penggunaan pecahan genteng dan fly ash berpengaruh terhadap kuat tekan segmen kolom modular. Kuat tekan segmen kolom beton meningkat pada penambahan pecahan genteng pada prosentase penggantian $20 \%$ terhadap pasir. Sedangkan penambahan fly ash berpengaruh semakin kuat hingga penambahan $30 \%$ dari berbagai prosentase penggunaan pecahan genteng.

b. Penggunaan pecahan genteng dan fly ash berpengaruh terhadap beban aksial komponen kolom. Beban aksial komponen kolom meningkat pada penambahan pecahan genteng pada prosentase penggantian $20 \%$ terhadap pasir.
Sedangkan penambahan fly ash berpengaruh semakin kuat hingga penambahan $30 \%$ dari berbagai prosentase penggunaan pecahan genteng.

c. Nilai optimal penambahan pecahan genteng dan fly ash yang menghasilkan kuat tekan maksimum pada segmen kolom modular sebesar 13,95 $\mathrm{MPa}$ pada prosentase penggantian $20 \%$ pecahan genteng dan penambahan fly ash sebesar $30 \%$.

d. Nilai optimal penggunaan pecahan genteng dan penambahan fly ash yang menghasilkan beban aksial maksimum pada komponen kolom sebesar 133,33 KN pada prosentase penggantian $20 \%$ pecahan genteng dan penambahan fly ash sebesar $30 \%$.

e. Hasil penelitian digunakan sebagai suplemen mata kuliah teknologi beton.

2. Saran

Berdasarkan simpulan dan implikasi hasil penelitian pembahasan, maka dapat dikemukakan saran-saran sebagai berikut:

a. Perlu adanya pengembangan penelitian lebih lanjut untuk

${ }^{1}$ Mahasiswa Program Studi Pendidikan Teknik Bangunan FKIP UNS.

${ }^{2}$ Pembimbing I Chundakus Habsya

3 II Taufiq Lilo Adi S 
pemanfaatan pecahan genteng sebagai bahan pengganti agregat halus maupun kasar pada beton. Untuk penelitian selanjutnya penggunaan pecahan genteng yang mendapatkan kekuatan maksimal bisa menggunakan pecahan genteng dengan jenis lainnya.

b. Perlu adanya pengembangan penelitian lebih lanjut untuk pemanfaatan fly ash sebagai bahan tambah pada beton. Pada penelitian berikutnya penambahan fly ash bisa ditambahkan prosentasenya. Kekuatan beton dengan penambahan fly ash terus meningkat hingga prosentase $30 \%$.

c. Perlu adanya pengembangan tentang segmen kolom. Pada penelitian selanjutnya pengujian komponen kolom bisa menggunakan sampel dengan tinggi 3 meter supaya benda uji sesuai dengan kondisi kolom di lapangan.

\section{DAFTAR PUSTAKA}

,(1991). Standar Nasional Indonesia T-15-1991-03. Tata Cara Perhitungan struktur Beton untuk bangunan gedung. Departemen Pekerjaan Umum

,(1992). Standar Nasional Indonesia 03-2834-1992. Tata Cara Pembuatan Rencana Campuran Beton. Badan Standarisasi Nasional

,(2002). Standar Nasional Indonesia 03-2847-2002. Tata Cara Perhitungan Struktuk Beton Untuk Bangunan Gedung . Badan Standarisasi Nasional

ACI. Manual of Concrete Practice. 1993 parts $1226.3 \mathrm{R}-3$

Adi S. (2007). Pengaruh Penggunaan Limbah Pecahan Genteng Keramik Pada Beton K-175. Jurnal Vol.1, No.1 . Program Studi Teknik Sipil Politeknik Balikpapan.

Asroni, Ali. (2010). Balok dan Pelat Beton Bertulang. Yogyakarta : Graha Ilmu

Bagus,Ginanjar P. (2015). Tinjauan Kuat Tekan Beton Geopolymer Dengan Fly Ash Sebagai Bahan Pengganti Semen. Naskah Publikasi. Program Studi Teknik Sipil Fakultas Teknik Universitas Muhammadiyah Surakarta

Claudia, dkk. (2006). Modul Pelatihan Pembuatan Ubin Atau Paving Blok Dan Batako. Jakarta. ILO ISBN 92-2-819590-3.

Djiwantoro H.,(2001): Abu Terbang Solusi Pencemaran Semen, Sinar Harapan, Jakarta

${ }^{1}$ Mahasiswa Program Studi Pendidikan Teknik Bangunan FKIP UNS.

${ }^{2}$ Pembimbing I Chundakus Habsya

$3 \quad$ II Taufiq Lilo Adi S 
Karyaningrum, N. A. (2011). Tinjauan Kuat Lentur Rangkaian Dinding Panel Dengan Tulangan Baja dan Agregat Pecahan Genteng, Tugas Akhir, Jurusan Teknik Sipil, Fakultas Teknik, Universitas Muhammadiyah Surakarta

Mashadi,Ahmad.,dkk.

(2009).

Pengartuh Variasi Campuran Kerikil Dengan Pecahan Genteng Terhadap Kualitas Paving Block. Jurnal Vol.32, No.2 . Fakultas Teknik Universitas Tidar Magelang.

Munir,Misbachul. (2008). Pemanfaatan Abu Batubara (Fly Ash) Untuk Hollow Block Yang Bermutu Dan Aman Bagi Lingkungan. Tesis . Program Studi Ilmu Lingkungan Universitas Diponegoro.

Nagy, John R and Krell, Clinton C. (2012). Modular Concrete Building. Paten US8,132,388B2. Tanggal 13 Maret 2012

Nugraha, Paul dan Antoni. 2007. Teknologi Beton dari Material, Pembuatan, ke Beton Kinerja Tinggi. Yogyakarta: ANDI

Ujianto, Muhammad. (2010), Tinjauan Kekuatan Dinding Panel Beton Ringan dari Limbah Pecahan Genteng, Proceeding Simposium Nasional RAPI IX 2010, Fakultas Teknik Universitas Muhammadiyah Surakarta.

Warsiti. (2007). Analisis Kuat Tekan Beton Campuran Pecahan Genteng Sebagai Pengganti Sebagian Agregat Kasar Beton Mutu Sedang. Jurnal Wahana TEKNIK SIPIL Vol. 12 No. 1,
Jurusan Teknik Sipil Politeknik Negeri Semarang. 